\title{
Somatic Embryogenesis from Anther, Whole Flower, and Leaf Explants of Some Grapevine Cultivars
}

\section{Maryam Karimi Alavijeh*, Ali Ebadi and Abdolkarim Zarei ${ }^{1}$ and Mansour Omidi²}

Department of Horticulture Science, Faculty of Agriculture, University of Tehran, Karaj, Iran-31587

Key words: Cultivar, Embryogenic calli, Media, Vitis vinifera

\begin{abstract}
To investigate the influence of cultivar, medium, and explants on production of somatic embryogenic callus in grapevine (Vitis vinifera) an attempt was made. After callus production, calli were transferred into GS1CA medium for embryogenesis. In GS1CA medium, anther explant of 'Shahroodi' cultivar showed the highest potential for production of embryogenic calli. Results showed that whole flower explants did not produce any embryogenic calli. In addition, leaf explants of 'Red-Sultanina' and 'Flame Seedless' were cultured on MS containing 1mg 2,4-D, $0.1 \mathrm{mg}$ BA, $1 \mathrm{~g} / \mathrm{l}$ casein hydrolisate, $20 \mathrm{~g} / \mathrm{l}$ sucrose and $7 \mathrm{~g} / \mathrm{l}$ agar were able to produce embryonic calli. After three months, calli were transferred to the MS with different concentrations of BA $(1,2$ and $3.5 \mathrm{mg} / \mathrm{l})$ and IAA $(2,5$ and $15 \mathrm{mg} / \mathrm{l})$. Results showed that among cultivars and different hormonal treatments, the medium containing $5 \mathrm{mg} / \mathrm{l} \mathrm{BA}$ and $2 \mathrm{mg} / \mathrm{l}$ IAA induced maximum embryogenesis in 'Flame-Seedless' calli.
\end{abstract}

\section{Introduction}

Grapevine (Vitis vinifera) is one of the most important fruit crops in the world and Iran in particular. The main center of diversity of $V$. vinifera is believed to stretch from Iranian Plateau to the South coast of the Black Sea and it is believed that Iran is among the primary areas of domestication and cultivation for this fruit (McGovern 2003, Terral et al. 2010). This fruit tree is grown in 307,721 ha in Iran, producing 2.15 million tons annually, ranking first among fruit crops in this country (FAO 2014). Due to the long history of grape cultivation, Iran has many

*Author for correspondence: <mkarimia61@gmail.com>. ${ }^{1}$ Department of Plant Biotechnology, Jahrom Universtiy, Jahrom, Iran, 74135-111. ${ }^{2}$ Department of Agronomy and Plant Breeding, Faculty of Agriculture, University of Tehran, Karaj, Iran. 
different grape cultivars. In spite of many advantages, commercial grape cultivars are facing some drawbacks including vulnerability to adverse climatic conditions as well as susceptibility to pest and diseases.

To improve grape cultivars, traditional classic methods have been employed for many years. However, classical methods for improving of fruit trees have some disadvantages including long juvenile periods, inbreeding depression, and incorporation of many unwanted characteristics to the progeny (Krul and Worley 1977, Gary and Benton 1991).

Somatic embryogenesis is considered as the most efficient method, especially when it is necessary to regenerate plants using genetically modified cells (George and Debergh 2008, Olah et al. 2009, Parimalan et al. 2011). This method is also an efficient tool for rapid propagation, somatic hybridization and somaclonal variation (Xu et al. 2005).

Somatic embryogenesis is a process in which differentiated and mitotically quiescent somatic cells recuperate embryogenic potential and differentiate new viable embryos that resemble zygotic embryos by re-programing gene expression (Chen et al. 2012. Due to its high potential of regeneration, somatic embryos are the most frequently adopted regeneration method in grapevine for gene transfer (Martinelly and Gribaudo 2009).

The use of somatic embryogenesis and the regeneration of plants have been studied for several cultivated species (Cardoso et al. 2012, Mishra et al. 2012, Ramakrishnan et al. 2013, Zhang et al. 2014). For grapevine embryogenesis, different explants, media and plant regulators have been tried and according to the reports, successful embryogenesis about this plant depends on several factors including medium (Perrin et al. 2001), genotype (Olah et al. 2009), explants type (Gambino et al. 2007), and explant developmental stages at the beginning of culture (Vidal et al. 2009). Genotype is an important factor affecting successfulness of somatic embryogenesis in grape and successful protocols have been produced for several genotypes (Perrin et al. 2004, Gribaudo et al. 2004, Xu et al. 2005).

Although somatic embryogenesis has been studied in some grapevine genotypes, but the procedure is not well established for many important cultivars (Kikkert et al. 2005).

Working with new cultivars or even cultivars which have grown in different climatic and soil conditions, requires further research to optimize embryogenic callus production procedures to determine convenient explants, medium, hormonal balance as well as culture conditions. To do so, in the present study, we studied the effects of explant types, kind and level of plant growth regulators as well as incubation conditions on embryogenic callus production in well- 
known cultivars of 'Red-Sultania', 'Flame-Seedless', and 'Perlette' as well as internally important cultivar of 'Shahroodi'. All of these cultivars are grown commercially in Iran, but they face problems which need improvement.

\section{Materials and Methods}

The inflorescence from Vitis vinifera L. cv. 'Flame-Seedless', 'Perlette', 'Shahroodi' and 'Red-Sultanina' were collected from the vineyard 10 - 12 days before anthesis with nearly impact flowers and anther color was transparent and some green (Fig. 1). In order to exert the chilling treatment, the inflorescences were kept in the sealed containers at $4^{\circ} \mathrm{C}$ for $24-48 \mathrm{hrs}$. Young leaves were collected from new seasonal growth of 'Red-Sultanina' and 'Flame-Seedless' vines. The size of the leaves was in the range of $2-5 \mathrm{~cm}$ and they did not show any pest or disease symptoms.
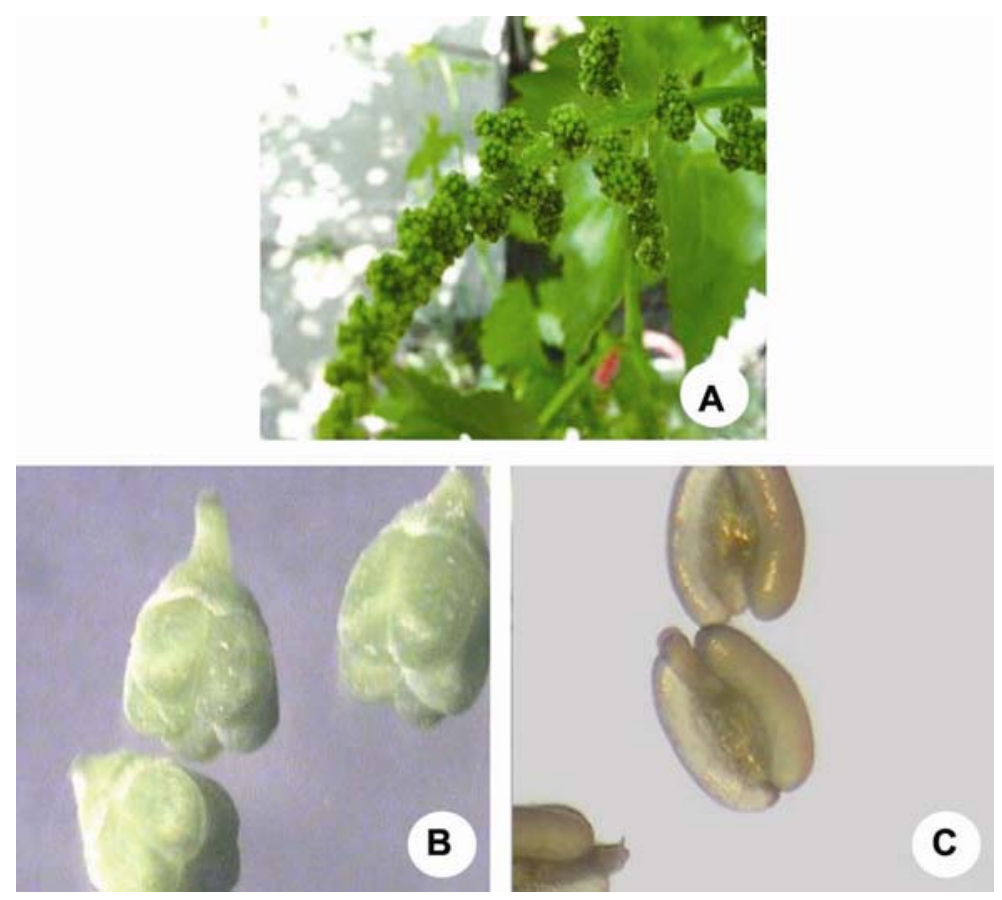

Fig. 1. Sampling stage and explants preparation. A. infloresence 10 - 12 days before anthesis. B. whole flower explants. C. anther explants.

In order to induce embryogenesis, calli produced from both explants were transferred to the GS1CA medium (NN macro, MS micro, B5 vitamin, Fe/EDTA, NOA (2-naohthoxyacetic acid) (2 mg/l), BAP (0.1 mg/l), IAA (3.2 mg/l). Temperature and light conditions were as in previous stage. Calli were 
subcultured at four-week intervals. Data recording was carried out in the GS1CA medium from callus after two months.

The leaves were rinsed with water for 15 - $20 \mathrm{~min}$, and then sterilized using $7 \%$ calcium hypochloride with 2 - 3 drops of Tween 20 for $10 \mathrm{~min}$. Then, they were rinsed three times with sterilized distilled water. In order to control the probable bacterial infection, gentamycin solution $(100 \mathrm{mg} / \mathrm{l})$ was used for $30 \mathrm{sec}$, then, the explants were rinsed again with sterilized distilled water. Leaf explants were cut to $1-2 \mathrm{~cm}$ segments and were cultured in Petri dishes containing the same medium which was used for anther and whole explants. MS containing 1 $\mathrm{mg} / 1$ 2,4-D, $0.1 \mathrm{mg} / \mathrm{l} \mathrm{BAP,} 1 \mathrm{~g} / \mathrm{l}$ casein hydrolysate, $20 \mathrm{~g} / \mathrm{l}$ sucrose, and $7 \mathrm{~g} / \mathrm{l}$ agar at $\mathrm{pH} 5.8$ was used for callus induction. Cultures were incubated at $25^{\circ} \mathrm{C}$ in dark and subcultured every 30 days.

Two months after culture and subculturing every 4 weeks, the calli with low growth, globular tissue and white to cream color were transferred to MS with 1, 2 and $3.5 \mathrm{mg} / \mathrm{l} \mathrm{IAA}$ and 2, 5 and $10 \mathrm{mg} / \mathrm{l} \mathrm{BAP}$ for rigorous induction of somatic embryos. The cultures were kept in dark at $25^{\circ} \mathrm{C}$ for the first month and then light intensity was increased to $10-12 \mu \mathrm{e} / \mathrm{m}^{2} / \mathrm{s}$ for the second month. In this type of callus, the embryos were observed in the primary stage during 2 weeks after transferring to foresaid light condition. During the next two weeks, light intensity reached to $45 \mu \mathrm{e} / \mathrm{m}^{2} / \mathrm{s}$ gradually and as time passed, heart shaped embryos were observed in the surface.

Data were recorded during the experiment and categorized based on callus texture. Data analysis performed using SPSS and EXCEL (drawing the graph) software.

\section{Results and Discussion}

Immature anthers, whole flowers, and leaf explants produced callus, but some of the anther explants initiated callus and the rest became black and died.

Both PIV and Harst media induced callus, but their differences was apparent on embryogenesis of the calli to GS1CA medium. Lopez et al. (2005) divided the calli into two groups: type I, which contained globular white or pale yellow texture, and type II with completely soft texture and pale brown color.

Calli which were produced from anther and whole flower explants in Harst and PIV media, were studied from the point of callus type six weeks after their transfer to GS1CA medium. Calli were divided into one of the three types: watery, powdery and compact tissue, based on their tissue quality. Previous reports (Perrin et al. 2004, Lopez et al. 2005, Gambino et al. 2007) showed that embryo production is dependent on callus morphology. In this categorization, 
watery calli (Fig. 2A) were those which did not have the ability of embryogenesis. These calli were dissipated with the scalpel. Powdery calli (Fig. 2B) were in white color and looked like a bulk. These calli were not embryogenic. Compact tissues (Fig. 2C) were those, which did not dissipate and were milky color. These tissues, in some of their sections, produced globular structure that showed to have the ability to be converted to heart and torpedo shape embryos (Fig. 2D). According to Marsoni et al. (2008), embryogenic callus are those which are translucent in color and more friable, whereas non embryogenic callus appeared to be spongy. Also $\mathrm{Xu}$ et al. (2005) observed higher frequency of somatic embryo in white, friable and crystal like callus than watery and loose ones.
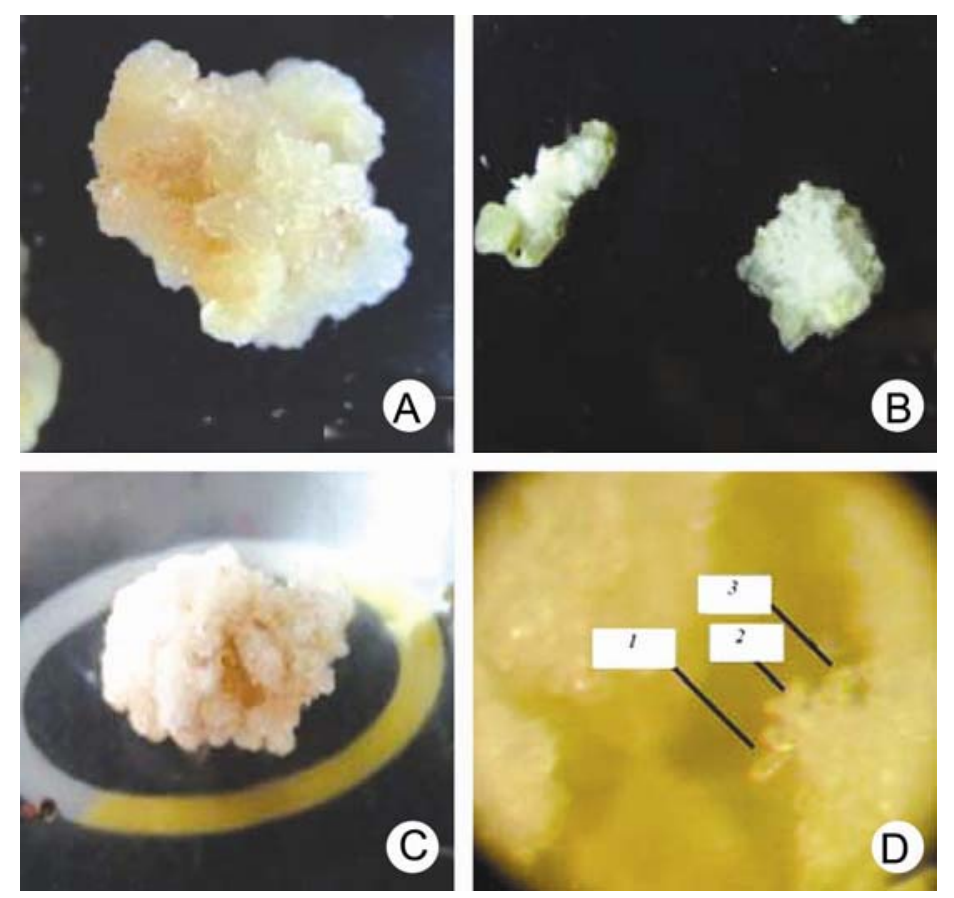

Fig. 2. Different types of calli: A. Callus with watery texture. B. Callus with powdery texture. C. Callus with compact texture. D. Eembryos in different stages (1. globular, 2. heart and 3. torpedo).

Results showed that, type of cultivar affects callus texture. Among cultivars, the most watery and powdery texture were recorded for 'Perlette' $(43.3 \%)$ and 'Red-Sultanina' (37.5\%). Therefore, they did not produce any embryogenic callus in GS1CA medium. 'Shahroodi' showed the highest percentage (52.6) of compact texture calli that is an assurance for the embryogenesis in the next steps, while 'Perlette' did not produce any embryogenic callus (Fig. 3). 


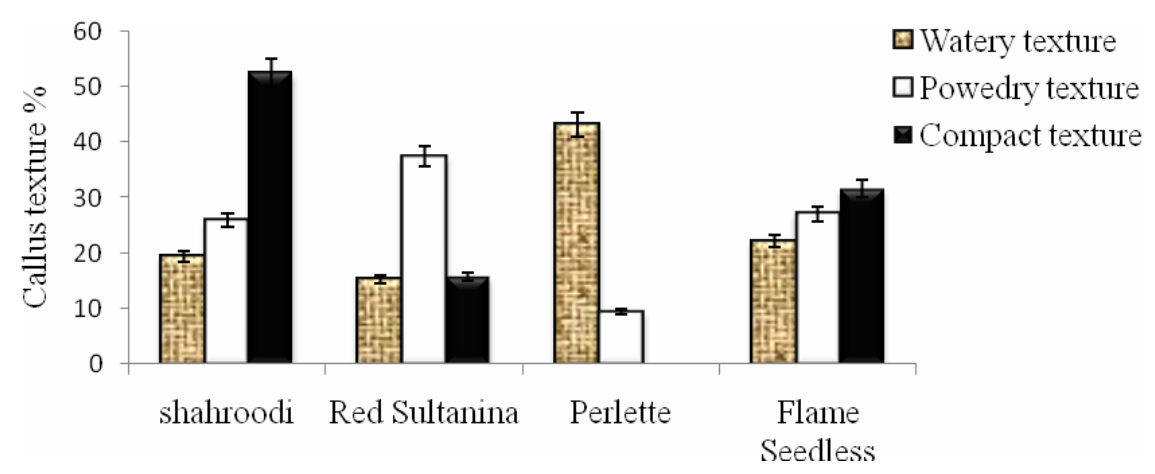

Fig. 3. Effect of cultivars on calli type produced from anthers and flowers.

The most important factor for inducing embryogenesis in callus, is the level of plant growth regulators in the culture medium. With regard to differences among the cultivars, it could be concluded that each and every cultivar has special need for exogenous growth regulators, which can be resulted in special response, when it establishes in an appropriate medium. These factors may affect the success of any cultivar to produce the embryogenic callus. Kikkert et al. (2005) reported that there were significant differences among genotypes for embryogenesis. This factor strongly affected induction of embryogenesis and the type of produced embryogenic tissue. The compact calli were produced from anther explants and had the embryogenic characteristics. These results are in agreement with Lopez et al. (2005) who reported the highest amount $(52.5 \%)$ of embryogenic callus in cultivar 'Sugraone' from anther explants. Perl et al. (1996) reported that the amount of embryogenic callus in 'Suprior-Seedless' was 30.4\%, while according to Mauro et al. (1986), the corresponding amount was $43.6 \%$ in 'Cabernet-Sauvignon'. In another similar work, Bouquet et al. (1982) reported $51.3 \%$ embryogenic calli formation from anther explants in $V$. riparia. However, Kikkert et al. (1997) showed a low frequency of embryogenesis $(0.1-3 \%)$ in anther cultures of Vitis $\times$ Labruscana, after about one year. Xu et al. (2005) reported high per cent of somatic embrogenesis from immature ovules in some $V$. rotundifolia and $V$. vinifera cultivars. These results may confirm the idea that genotypes as well as species are important factors for embrogenic callus formation in grapevine.

Anther explants found to be mostly successful for producing the compact texture callus, and all of these calli converted to embryo in three 'Shahroodi', 'Red-Sultanina', and 'Flame-Seedless' cultivars. However, 'Perlette' did not produce any embryogenic callus. Whole flower explants in all the three cultivars did not produce embryogenic callus and most of their calli were powdery or 
watery (Fig. 4). Generally, the embryogenic calli had low growth rate, compact texture, white to yellow color and globular shape. In our work, these types of calli (EC) were obtained only from anther and leaf explants. Direct contact of anther explants with medium surface has probably a prominent role on embryogenic callus production. Since, the anther explants do not have perianth tissue (sepal, petal, etc.), they established more effectively in the medium compared with the whole flower that had such organs. Therefore, in this trial, anther was the most suitable explants in the tested cultivars for producing embryogenic callus. Gambino et al. (2007) reported that the big size of whole flower explants may increase lag phase in response to growth regulators, and might be the reason of delay in production of embryos. They also observed that callus from whole flower culture in 'Chardonnay', 'Muller Thurgau', 'Grignolino' and '110R' had potential to produce embryogenic callus, but the same explants in cv. 'Brachettog. l' did not produce any embryo. Nevertheless, it seems that medium, environmental conditions and cultivar response were not set completely in our work for whole flower explants and it needs further investigations.

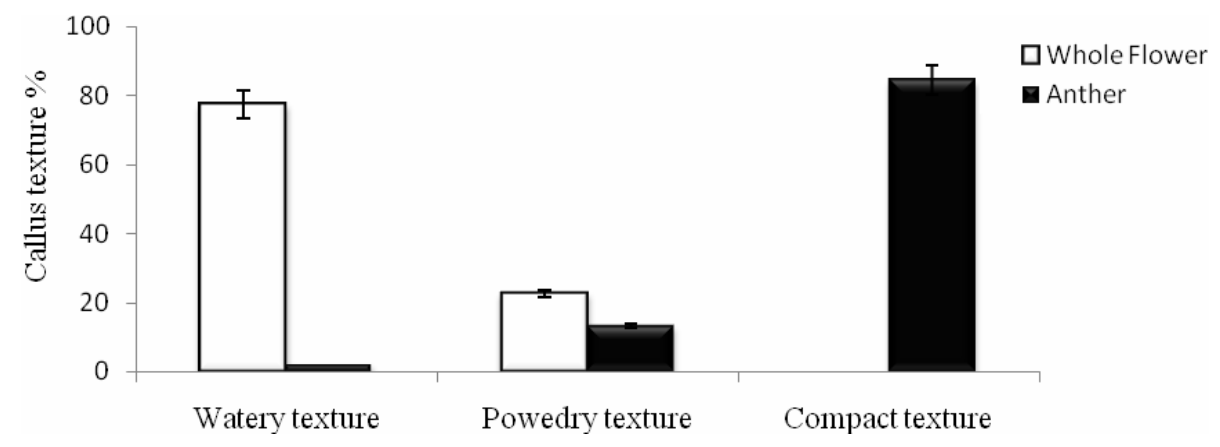

Fig. 4. Effect of explants on type of callus (watery, soft and dispersible).

In another trial, leaf explants in two cultivars, namely 'Red-Sultanina' and 'Flame-Seedless' were examined. The texture of callus from these explants was similar to those of anther calli (Fig. 5). This callus was assessed for embryo production in MS with 1, 2 and $3.5 \mathrm{mg} / 1 \mathrm{IAA}$ and 2, 5 and $10 \mathrm{mg} / \mathrm{l} \mathrm{BAP}$. The $\chi^{2}$ test showed that the effects of cultivar was significant at 0.01 level for producing somatic embryos $\left(\chi^{2}=9.39, \mathrm{p}=0.01\right)$.

Results from leaf explant indicated that, compared to 'Red-Sultanina' $(31.4 \%)$, 'Flame-Seedless' showed better response (68.6\%) for embryogenesis in the media for this explant (Fig. 6). The effect of culture media on embryogenesis might be due to balance of growth regulators of tissue as well as their external treatments. 
Das et al. (2002) observed that 'Pussa-Seedless' in MS containing $1 \mathrm{mg} / \mathrm{l} \mathrm{IAA}$ and $1 \mathrm{mg} / \mathrm{l} \mathrm{BAP}$ produced the most embryogenic callus among the other cultivars ('Beauty-Seedless', 'Pussa-Seedless', 'Perlette' and 'Nashik'). In another attempt, Passos et al. (1999) were able to produce callus from the leaf explants in some grape cultivars, but those calli did not produce any embryo.
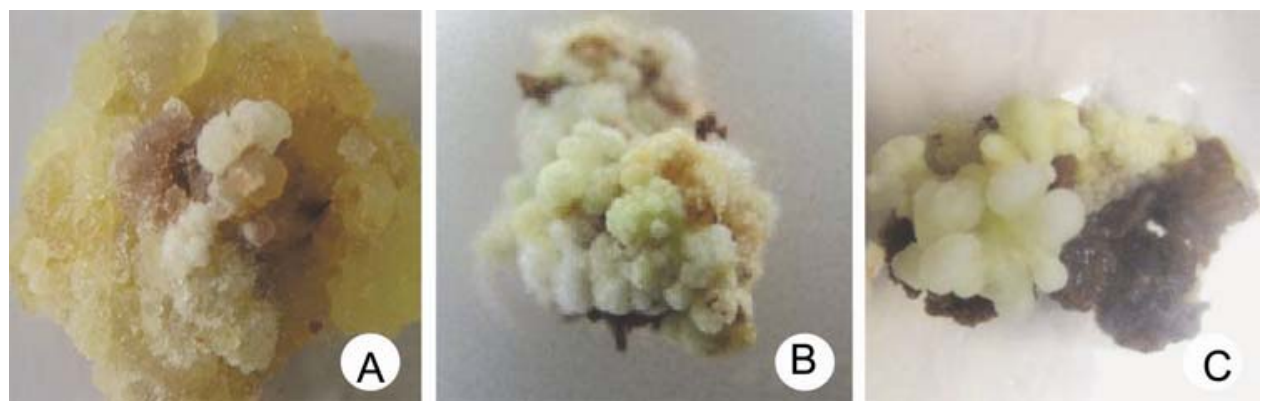

Fig. 5. Type of calli obtained from leaf explants. A. Normal callus in initiation medium.

B. Embryogenic callus in dark condition. C. Embryo formation in light condition.

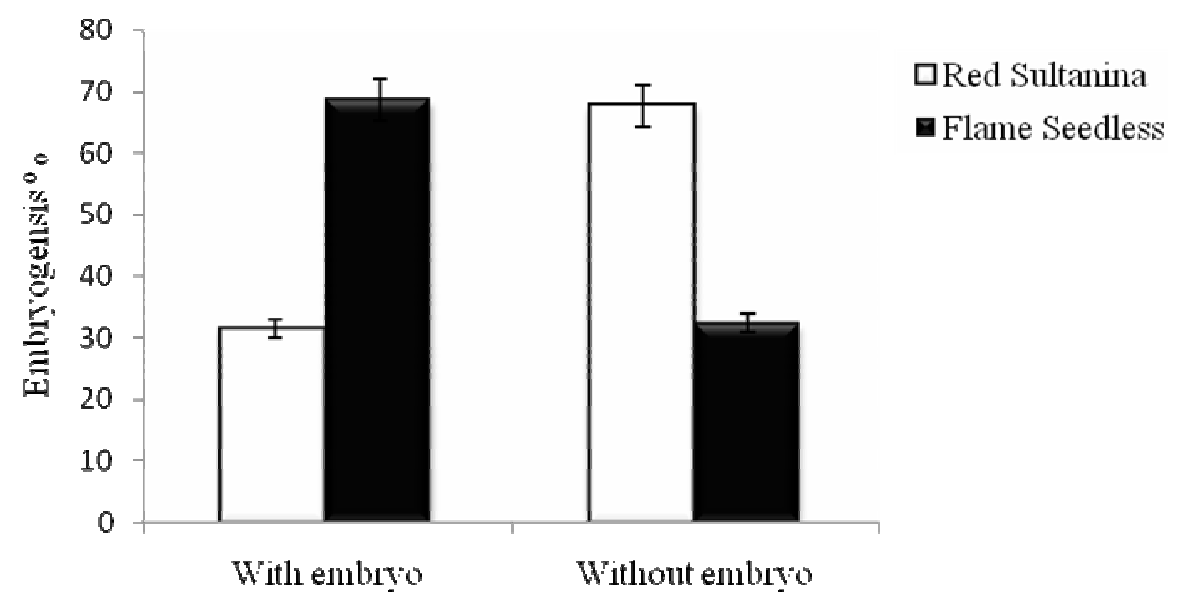

Fig. 6. Effect of cultivar on embryogenesis.

To study the effects of growth regulator treatments on somatic embryogenesis in the leaf explants, another trial was carried out with nine hormonal complex (BAP: 2, 5 and $10 \mathrm{mg} / \mathrm{l}$, IAA: 1, 2 and $3.5 \mathrm{mg} / \mathrm{l}$ ) in MS. Effect of treatments was significant $\left(\chi^{2}=28.46, p=0.01\right)$. Among the hormonal treatments, the medium containing $2 \mathrm{mg} / \mathrm{l} \mathrm{IAA}$ and $5 \mathrm{mg} / \mathrm{l} \mathrm{BAP}$ showed to be the optimal medium for embryogenesis. However, media with the same amount of IAA but different BAP concentrations did not induce embryogenic callus (Fig. 7). Combination of 2,4-D and BAP for production of callus from leaf explants was 
investigated by workers (Robacker 1993,Torregrossa et al. 1995), and Matsyta (1992) produced somatic embryos using 2,4-D in leaf explants.

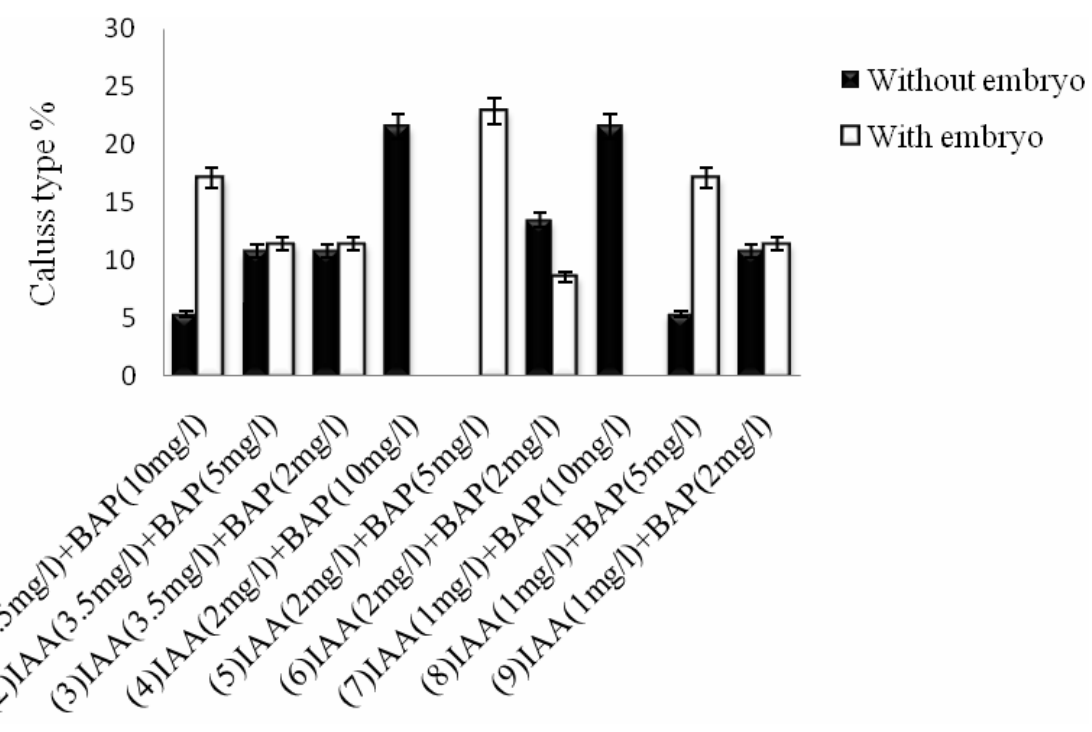

Fig. 7. Effect of different hormonal complex on embryogenic callus induction.

Lopez et al. (2005) working with 'Surgraone' and 'Crimson-Seedless' showed that embryogenic callus production is directly related to BAP concentration in the medium $(1.3 \mathrm{mg} / \mathrm{l})$. Effects of different concentrations of BAP and 2,4-D on the embryogenesis in the leaf explants were studied by Das et al. 2002. Although IAA $(0.1 \mathrm{mg} / \mathrm{l})$ and BAP $(1.5 \mathrm{mg} / \mathrm{l})$ have been reported to induce embryogenic callus in grape (Popescu 1996), the use of NN medium supplemented with IAA $(1.7 \mathrm{mg} / \mathrm{l})$ and BAP $(2 \mathrm{mg} / \mathrm{l})$ did not induce the formation of somatic embryos in anther-derived callus (Salunkhe et al. 1999). Matsuta and Hirabayashi (1989) reported that the lack of either 2,4-D or BAP, or both, in the medium is known to be detrimental for induction of somatic embryos in $V$. vinifera cell lines. Our results indicated that only the MS supplemented with $0.1 \mathrm{mg} / 1$ 2,4,-D and 1mg/l BAP induced the embryogenesis in the leaf explants which is in agreement with Popescu (1996) and Matsuta and Hirabayashi (1989). Results of another work on grape cv. 'Seyval-Blanc', the NN medium with $4 \mathrm{mg} / 1 \mathrm{NOA}$ and $0.9 \mathrm{mg} / \mathrm{l} \mathrm{TDZ}$ showed the highest percentage of embryogenic callus production (Reustle et al. 1995). Results of present study revealed that, applied hormonal treatments (IAA $2 \mathrm{mg} / \mathrm{l}$ and BAP $5 \mathrm{mg} / \mathrm{l}$ ) were very effective in embryogenesis in 'Red-Sultanina' and 'Flame-Seedless'. It can also be concluded that internal level of hormones in 
any cultivar and its interaction with applied external hormones are very effective in embryogenic callus production.

\section{References}

Bouquet A and Lamaison B (1982) Influence du genotype sur la production de cals, d embryoides et de plantes entieres par culturedantherInvitrodans le genre vitro dans le genre. Vitis. CR Acad. Sci. 295: 569-574.

Cardoso JC, Martinelli AP and Latado RR (2012) Somatic embryogenesis from ovaries of sweet orange cv. Tobias. Plant Cell Tiss. Org. Cult. 109: 171-177.

Chen K, Wu HJ, ChenJF, Cheng XF, Jing X and Wan XY (2012) Somatic embryogenesis and mass spectrometric identification of proteins related to somatic embryogenesis in Eruca sativa. Plant Biotechnol. Rep. 6: 113-122, DOI 10.1007/s11816-011-0203-2

Das DK, Reddy MK, Upadhyaya KC and Sopory SK (2002) An efficient leaf-disc culture method for the regeneration via somatic embryogenesis and transformation of grape (Vitis vinifera L.). Plant Cell Rep. 20: 999-1005.

FAO (2014) Statistical database.

Gambino G, Ruffa P, Vallania R and Gribaudo I (2007) Somatic embryogenesis from whole flowers, anthers and ovaries of grapevine (Vitis spp.). Plant Cell Tiss. Org. Cult. 90: 79-83.

Gary D and Benton C (1991). In vitro micro propagation and plant establishment of muscadine grape. Plant Cell Tiss. Organ. Cult. 27: 7-14.

George EF and Debergh PC (2008) Micropropagation: Uses and methods. In: George, E.F., M.A. Hall, and G.-J. De Klerk (eds.). Plant propagation by tissue culture. 1. Springer, Dordercht, The Netherlands. pp. 29-64.

Gribaudo I, Gambino G and Vallania R (2004) Somatic embryogenesis from grapevine anthers: The optimal developmental stage for collecting explants. Amer. J. Enol. Vitic.55: 427-430.

Kikkert JR, Ali GS, Striem MJ, Martens M, Wallace PG, Molino L and Reisch BI (1997) Genetic engineering of grapevine (Vitis sp.) for enhancement of disease resistance. Acta Hortic. 447: 273-279.

Kikkert JR, Strim MJ Vidal JR Wallce PG Barnard J and Reisch B (2005) Long-term study of somatic embrogenesis from anthers and ovaries of 12 grapevine (Vitis $\mathrm{sp}$.) genotypes. In Vitro Cell. Dev. Biol. Plant. 41: 232-239.

Krul WR and Worley JF (1977) Formation of adventitious embryos in callus cultures of Seyval a French hybrid grape. J. Amer. Soc. Hortic. Sci. 102: 360-363.

Lopez-perez AJ, Carreno J, Martinez A and Dabauza M (2005) High embryogenic ability and plant regeneration of table grapevine cultivars (Vitis vinifera L.) induced by activated charcoal. Vitis 44: 79-85.

Marsoni M, Bracale M, Espen L, Prinsi B, Negri SA and Vannini C (2008) Proteomic analysis of somatic embrogenesis in Vitis vinifera L. Pla. Cel. Rep. 27: 347-356.

Martinelly L and Gribaudo I (2009) Grapeving Molecular Physiology and Biotechnology. Springer Verlag, Heidelberg. pp. 481. 
Matsuta N and Hirabayashi T (1989) Embryogenic cell line from somatic embryos of grape (Vitis vinifera L.). Plant Cell Rep. 7: 684-687.

Matsyta N (1992) Effect of auxin on somatic embryogenesis from leaf callus in grape (Vitis spp.) Jpn. J. Breed. 42: 879-883.

Mauro MCl, Nef C and Fallot J (1986) Simulation of somatic embryogenesis and plant regeneration from anther culture of Vitis vinifera cv. Cabernet-Sauvignon. Plant Cell Tiss. Org. Cult. 5: 377-380.

McGovern PE (2003) Ancient Wine: The Search for the Origins of Viniculture. Princeton University Press. pp. 392.

Mishra S, Sanyal I and Amla DV (2012) Changes in protein pattern during different developmental stages of somatic embryos in chickpea. Biol. Plant. 56: 613-619.

Olah R, Zok A, Pedryc A, Howard S and Kovacs LG (2009) Somatic embryogenesis in a broad spectrum of grape genotypes. Sci. Hortic. 120 : 134-137.

Parimalan R, Venugopalan A, Giridhar P and Ravishankar GA (2011) Somatic embryogenesis and Agrobacterium-mediated transformation in Bixa orellana L. Plant Cell Tiss. Org. Cult. 105 : 317-328.

Passos IRS, Appezzato-Da-Glora B and Vienera MLC (1999) Embryogenic responses of Vitis spp.: Effect of genotype and polyvinyl pyrrolidone. Vitis. 38: 47-50.

Perl A, Gollop A, Lipsky A, Holland D, Sahar N, Or E and Elyasi R (1996) Regeneration and transformation of grape (Vitis vinifera L.). Plant. Tiss. Cul. and Biot. 2: 188-193.

Perrin M, Gertz C and Masson JE (2004) High efficiency initiation of regenerable embryogenic callus from anther filament of 19 grapvine genotypes grown worldwide. Pla. Sci. 167: 1343-1349.

Perrin M, Martin D, Joly D, Demangeat G, This P and Masson JE (2001) Mediumdependent response of grapevine somatic embryogenic cells. Plant Science 161: 107-116.

Popescu CF (1996) Somatic embryogenesis and plant development from anther culture of Vitis vinifera L. Plant Growth Reg. 20: 75-78.

Ramakrishnan M, Ceasar SA, Duraipandiyan V, Daniel MA and Ignacimuthu S (2013) Efficacious somatic embryogenesis and fertile plant recovery from shoot apex explants of onion (Allium cepa L.). Vitro Cell. Dev. Biol. Plant. 49 : 285-293.

Reustle G, Harst M and Alleweldt G (1995). Plant regeneration of grapevine (Vitis sp.) protoplast isolated from embryogenic tissue. Plant Cell Rep. 15: 238-241.

Robacker C (1993) Somatic embryogenesis and plant regeneration from muscadine grape leaf explants. Hort. Sci. 28: 53-55.

Salunkhe CK, Rao PS and Mhatre M (1999) Plantlet regeneration via somatic embryogenesis in anther callus of Vitis latifolia L. Plant Cell Rep. 18: 670-673.

Terral JF, Tabard E, Bouby L, Ivorra S, Pastor T, Figueiral I, Picq S, Chevance JB, Jung C, Fabre L, Tardy C, Compan M, Bacilieri R, Lacombe T and This P (2010) Evolution and history of grapevine (Vitis vinifera) under domestication: New morphometric perspectives to understand seed domestication syndrome and reveal origins of ancient European cultivars. Ann. Bot. 105: 443-455, doi: 10.1093/aob/mcp298 
Torregrossa L, Torres-Vials M and Bouquet A (1995) Somatic embryogenesis from leaves of Vitis $\times$ Muscadinia hybrids.Vitis. 34: 239-240.

Vidal J R, Rama J, Taboada L, Martin C, Ibanez M,Ssegura A and Gonzales-Benito E (2009) Improved somatic embryogenesis of grapevine (Vitis vinifera) with a focus on induction parameters and efficient plant regeneration. Plant Cell, Tiss. Org. Cul. 96: 85-94.

Xu X, Lu J Ren, Z Wang H and Leong S (2005) Callus induction and somatic embryogenesis in muscadine and seedless bunch grapes (Vitis) from immature ovule culture. Proc. Fla. State Hort. Soc. 118: 260 -262.

Zhang Q, Folta KM and Davis TM (2014) Somatic embryogenesis, tetraploidy, and variant leaf morphology in transgenic diploid strawberry (Fragaria vesca subspecies vesca 'Hawaii 4') (online). BMC Plant Biol. 14: 14-23. 